\title{
This Special Issue of Microsystem Technologies is devoted to Professor Dr.-Ing. Jürgen Haußelt on the occasion of his 65th birthday
}

\author{
Karl-Heinz Zum Gahr • Bernd Michel
}

Published online: 3 April 2011

(C) Springer-Verlag 2011

Professor Dr.-Ing. Jürgen Haußelt, for many years the Head of the Institute of Materials Research III at the Forschungszentrum Karlsruhe, today Karlsruhe Institute of Technology (KIT), and also Professor and Head of the Laboratory of Materials Process Technology at the University of Freiburg will be celebrating his 65th birthday on May 21, 2011. His outstanding professional career features about 16 years of work in industry and 24 years in science and teaching at academic and research institutions.

Jürgen Haußelt studied physics at the University of Erlangen-Nürnberg in Bavaria, Germany, and finished his diploma thesis in 1971. Under the guidance of the Professors Bernhard Ilschner and Wolfgang Blum at the Institute of Materials Science of the university he accomplished a $\mathrm{PhD}$ thesis on the recovery of the dislocation structure after stationary deformation with an Al-Zn alloy. After being awarded his doctoral degree (Dr.-Ing.) in 1975, he worked as a scientific assistant at this institute and during this time he took a year-long sabbatical for a postdoc position with Prof. W.D. Nix at Stanford University, USA.

Back from the USA, Jürgen Haußelt started his industrial career in July 1977 as group leader in the Metal Research Department of Degussa AG at Hanau-Wolfgang, Germany. At the beginning he worked on the development of new alloys for dental and brazing technologies. In 1983 he became the Technical Director of Degussa Dental, Inc.

K.-H. Zum Gahr ( $($ )

Karlsruhe Institute of Technology, Karlsruhe, Germany

e-mail: karl-heinz.zumgahr@kit.edu

B. Michel

Micro Materials Centers Berlin and Chemnitz, Berlin, Germany

e-mail: bernd.michel@enas.fraunhofer.de at Long Island City, USA. As consequence of his remarkable success, he was promoted in November 1984 to the position of the division manager 'Metallurgy' at Degussa-Metal Research at Hanau-Wolfgang. The next steps of his career at Degussa had been appointments to a department head in 1987 connected with an enlargement of responsibilities for electronic materials, thin film materials and structural ceramics and in 1989 to the department director "Manufacturing Technology" with responsibility for the Central Research "Metal" which included melting and casting techniques as well as metal forming and powder metallurgy.

A new phase of Jürgen Haußelt's life began on October 1, 1993 with the acceptance of the position of Head of the Institute of Materials Research III at the Kernforschungszentrum Karlsruhe which was renamed Forschungszentrum Karlsruhe in 1995. In 1996 he was additionally appointed Professor and Head of the Laboratory of Materials Process Technology at the Department of Microsystems Engineering (IMTEK) at the University of Freiburg. Promoted by the two appointments of Jürgen Haußelt, a close scientific and personal cooperation of both institutions has developed in the field of Microsystems Technology, particularly. Credit is due to him also for his considerable contribution as vice-spokesman to the formation of the DFG-Collaborative Research Centre 499 "Design, production and quality assurance of moulded microcomponents made of metallic and ceramic materials".

By reason of his outstanding scientific competence in several fields of materials science and process technologies for microsystems but also due to his charismatic and engaging personality, his membership in numerous executive and scientific committees has been very much appreciated. Beside his manifold activities in the science community and as a university professor, Jürgen Haußelt 
has been an excellent scientist that is documented by more than 290 publications and 140 patents.

His 65th birthday is a suitable occasion for his staff members, colleagues and long-time friends to thank Professor Jürgen Haußelt for his advice, many stimulating talks and scientific discussions, as well as to wish him and his family a healthy and enjoyable future.

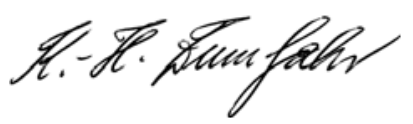

Prof. Dr.-Ing. Karl-Heinz Zum Gahr

Karlsruhe Institute of Technology (KIT)

Guest Editor

B. Mild

Prof. Dr. rer. nat. Bernd Michel

Micro Materials Centers Berlin and Chemnitz

Editor-in Chief of Microsystem Technologies 